\title{
Are Trade Liberalization and Democracy Driving Development in Central Africa Region? Empirical Lessons
}

\author{
Tchouassi, Gérard \\ University of Yaoundé, Cameroon, Central Africa \\ tchouassigerard@yahoo.fr
}

\begin{abstract}
This paper documents that trade liberalization and democracy contribute positively to economic development. A panel of 11 Central Africa countries with 176 observations from 1995 to 2010 was used to econometrically verify this assertion. Estimation using the general least square (GLS) with the overall $\mathrm{R}$-square $\left(R^{2}=0.0325\right)$ shows that there is a relationship between the economic development captured here with Human development indicators (HDI), democracy, importations, exportations, inflation and regional integration. Inflation and exports negatively affect the well-being of the population. An increase in inflation rate causes a reduction in purchasing power. An increased in exports commodities tends to decrease the quantity of goods available for the country of origin. Imports have a positive effect on HDI probably because this variable tends to increase the quantity of goods available. Imports and democracy have a positive effect on the level of development among Central African countries. The paper's findings are important to Central Africa policy makers towards creation and increasing trade within, between and with other democratic countries.
\end{abstract}

Keywords: Trade, democracy, development, well-being, regional integration, Central Africa.

\section{Introduction}

Liberalization was presented to the developing poor countries as providing a way out of inefficient strategies associated with trade protection and high levels of State intervention, as well as the rentseeking (Krueger, 1974) behavior that those strategies encouraged. It was also brought forward as a channel of fully exploiting the opportunities generated by globalization. Free trade by definition involves greater interdependence among countries, and is currently linked to the phenomenon of globalization. There is a consensus that developing, autocratic or democratic, countries have a great deal to gain from free trade. The origin of the literature on international trade goes back to Adam Smith (1776). Recent literature on trade liberalization and economic reform dates to the 1970s with publications by Little et al. (1970), followed by Krueger (1974). Trade liberalization indicates the process whereby a country opens up its markets to international trade. It also often comes alongside increased rights for investors and pressures to privatize the economy. Trade liberalization can be a good thing in the right circumstances, if it's phased in correctly at the right time in a country's development. However for many years European Union countries have used institutions like the World Bank and International Monetary Fund, conditions attached to aid and trade deals like those negotiated at the World Trade Organization to force developing poor countries to liberalize their economies. Economic Partnership Agreements are part of the same trend. There is now ample evidence which shows that this liberalization agenda actually increases poverty, especially when imposed from outside and not driven by country needs and timetables. Democratization is more of an abstract enterprise, centering on multi-party systems and national elections at regular intervals. It cannot be granted that democratization actually leads to a democratic society. On the contrary common fusing with patrimonial politics in the postcolonial state often leads to anti-democratic patterns. Gradual increased access to information (free media and the electronic information boom) is indeed of great importance. But even this access and communication possibilities do not in themselves lead to democratization (Arnfred and Utas, 2007). Different patterns of democratization are often used to explain other political phenomena. Democratization itself is influenced by various factors, including economic development, history, and civil society. There is considerable debate about the factors which affect or ultimately limit democratization.

Democracy and market economy are intrinsically linked (Mousseau, 2000). This belief generally centers on the idea that democracy and market economy are simply two different aspects of freedom. A widespread market economy culture may encourage norms such as individualism, negotiations, compromise, respect for the law, and equality before the law. These are seen as supportive for 
democratization. Measuring varieties of democracy, Coppedge and Wolfgang (1990) identify four innovations. First, rather than attempting to produce a single simple rating of "democracy", it seeks to capture six different conceptions of democracy: the pared-down, "minimalist" concept of electoral democracy, which is the foundation on which most of the other conceptions build; liberal democracy, which adds guarantees of basic civil and political rights and institutes checks and balances to guard against the tyranny of the majority; majoritarian democracy-partially at odds with liberal democracywhich concentrates power in the hands of the majority; participatory democracy, which encourages the involvement of citizens in many stages of the political process; deliberative democracy, which requires governments to give reasoned and respectful justifications for their decisions; egalitarian democracy, which is inspired by the belief that political equality is unattainable without some degree of economic and social equality. Second, varieties of democracy radically disaggregate all these concepts. Each conception is broken down into several "components"-more than thirty altogether, including such components as regular elections, competitiveness, legislative power, sub national autonomy, gender equality, and free media. These components are, in turn, broken down into 316 specific indicators, each of which is measured separately. One of the key benefits of this degree of specificity is improved measurement reliability: one can judge more confidently whether any journalists were killed in a given year than what "level of media freedom" prevailed; one can more reliably judge whether the legislature can override an executive veto than how tight "executive constraints" were. Third, varieties of democracy are designed to have very broad historical and geographic coverage. To the extent possible, it is to rate all sovereign states and most non-sovereign territories, such as colonies, from 1900 to the present. This lengthy historical coverage is especially useful to scholars studying causal relationships because many of these relationships seem to unfold over decades rather than year to year or month to month. If scholars can develop a better understanding of the forces that create and sustain democracy, they will be better able to advice practitioners who seek to promote it. Finally, this project is designed to provide systematic estimates of the precision and reliability of its ratings. Other projects simply provide a score, such as a "3," with no indication of how accurate it is. Varieties of democracy would say that there is an 85 percent probability that such a score is a 3, for example, or that it is a "3, give or take 0.2 ". This does not mean that the existing indicators are more certain or precise; on the contrary, it means that we have no idea how imprecise they really are. No other major democracy index provides such estimates of precision and reliability. Calculating this information and making it public is essential for the responsible use of such data.

Defining development as an upward movement of the whole social system (Myrdal, 1971) it involves raising the standard of living of the population and providing them with employment. Development is considered here as well-being (material, social and security) enhancing and synonymous to a good quality of life. Some indicators of well-being are: rate of poverty, peace, freedom, life expectancy at birth, adult illiteracy, access to health care services, access to safe water, access to sanitation, infant mortality rate, maternal mortality rate, prevalence of malnutrition, population estimates, Gross Domestic Product per capita (World Bank, 2008). If there are systematic differences in trade integration between political regime types, this paper contributes to the broader debate about linking trade liberalization, democracy and economic development. This research is based on the theoretical and empirical evidences, particularly the prominent classical theory of international trade (Smith, 1776), the customs duties theories (Viner, 1950; Meade, 1956; Lipsey, 1957), the new theory of international trade (Krugman, 1991, 1996; Krugman and Obstfeld, 2006), the theory of regional integration (Balassa, 1960; Hugon, 1993; Hettne, 2000), the development theories (Perroux, 1961, 1972; Sen, 1999, 2000; Stiglitz, 1998), the link between democracy and development (Acemoglu et al., 2008; Acemoglu and Robinson, 2006). This paper attempts to answer the research question: Can trade liberalization and democracy help to channelize development in Central Africa region? The objective of the study is to show econometrically how democracy and trade flows are working for economic development in Central Africa countries. This paper uses a much larger data set and an updated empirical design to demonstrate that political regime differences in trade policy, while playing a role, cannot fully account for the observed differences in trade flows. The paper is organized as follows. Section one is introduction and section two reviews the relevant literature. Section three specifies the methodology and data. Section four presents the empirical results. Section five concludes. 


\section{Literature Review}

Why should a country in an early stage of development (Rostow, 1960) adopt democracy instead of authoritarianism? Different samples and periods tend to support the Washington Consensus (Williamson, 1990). Is democracy economically advantageous for poor countries? Is this in addition to its intrinsic merits? If we turn to Central Africa, is there little empirical evidence to show that recently open politics have helped to improve economic conditions (Serieux, 1999; Van de Walle, 1999; Feng, 1996). From 1981 to 1996, Central Africa countries experienced significant episodes of violent conflict between government and opposition groups. By 1998, some people lost their lives as a direct result of this democratic political violence, others became refugees. In illegitimate or quasi legitimate states, the state's own security forces often challenge the internationally recognized leadership. During the 1980s, many successful or unsuccessful military takeovers were recorded, affecting Central African countries and Central Africa economic integration. Still, it is important to observe that the region is not monolithic. Significant differences exist in democratic political institutions and practice. Moreover, none of the data suggest that the fledgling democracies do worse in the economic arena compared to rival systems. Given democracy's inherent value, that itself is a strong argument for continuing to favor political liberalization in Africa. In the new development strategy, trade plays a crucial role, although not through the mechanisms that economists have traditionally stressed (Stiglitz, 1998). The magic of comparative advantage is that a poor country benefits from trade. Even if, in absolute terms, its productivity is lower than its trade partners' across the whole range of goods. However, some authors have pointed to the gaps between the standard Hecksher-Ohlin trade model and what is observed in practice (Romer, 1994; Sachs and Warner, 1995). Clearly, something is missing from the standard story. The most important gains from trade may come from the increased variety of goods to which an open trading system offers access (Rodriguez-Clare, 1996; Stiglitz, 1997). That is, rather than just reducing the price of goods that are already available domestically, trade also offers access to many goods that simply were not available at any price under autarky. The new inputs bring down costs and spur innovation in the importing economy.

The issue of development and better distribution of world resources have long been components of the world trading system. It is widely recognized that there is a strong nexus between trade and development (Kwa, 2007; Wade, 2008). Meanwhile it is hard to refute the fact that international trade can be a powerful engine for a country economic development. The exact nature of the link between trade and development is constantly a subject of controversy within the ranks of academics and policy makers (Arnfred and Utas, 2007). Over time, the trade and development paradigm has shifted and this is reflected in the changes in the debate in the General Agreement on Tariffs and Trade and subsequently the World Trade Organization (WTO). Regarding the relationship between democracy and economic growth, Brunetti and Weder (1995) review twenty earlier empirical studies. Three studies discover a positive relationship, and five discover a conditional relationship, between democracy and growth. Ten crossnational studies fail to turn up any significant relationship. Only two of the studies find that democracy affects economic growth negatively. Goldsmith (2001) looked at an additional dozen studies on the same topic. Using increasingly sophisticated methods, they are even more favorable for representative government. Only one finds a negative correlation between democracy and growth or development (Gasiorowski, 2000). The other eleven find a positive, mixed, or neutral correlation. All of the following studies uncovered a positive association between democracy and growth or social well-being: Feng 1996; Wickrama and Mulford 1996; Leblang, 1997; Przeworski and Limongi, 1997; Fedderke and Klitgaard, 1998; Nelson and Singh, 1998; and Minier, 1998. None were detected by Burkhart and Lewis-Beck 1994. Inconclusive or mixed results were found by Helliwell (1994); Mbaku (1994); and Durham (1999). Analyzing the following questions: Is there a relationship between economic and political liberalization? Does a country's political regime systematically affect its involvement in international trade? According to Aidt and Gassebner (2010), the first question has recently received much attention. Related studies are on the determinants of democracy (Barro, 1999; Acemoglu et al., 2008), on the economic freedom (Boockmann and Dreher, 2003; Dreher and Rupprecht, 2007) and on the relationship between democracy and economic freedom (Sturm and de Haan, 2003; Giavazzi and Tabellini, 2005). Regarding the second question, research is scanty (Mansfield, Milner and Rosendorff, 2000; Morrow, Siverson, and Tabares, 1998). In this regard, Daumal (2008) finds that federalist systems increase international trade.

Milner and Kubota (2005) studying the relationship between political regime type and trade policy in a sample of developing countries show that democratic political institutions are associated with liberal trade policy. Other researchers have argued that international trade encourages democratization (Li and 
Reuveny, 2003; Rigobon and Rodrik, 2005; Lopez-Cordova and Meisner, 2008). New studies indicate that political regime can influence the involvement in international trade. In this vein, Aidt and Gassebner (2010) find that autocracies trade less than democracies. Furthering the theoretical and empirical debates into areas of trade and peace, this relation is still inconclusive (Barbierie, 1996, 2003; Oneal and Russet, 1999, 2003; Polachek, 1980, 2007; Long, 2008; Martin et al., 2008). According to Draper (2010), it is important to contextualize the debate over the role of African states in the development of their countries and the associated "good governance" agenda. Ohno (2009) define democratic developmentalism to be "a political regime in which a developmental party remains in power for a long time by consecutively winning free elections which permit multiple parties, under which policies that punish rent-seeking and encourage productive investment are implemented with a strong state guidance". Arnfred and Utas (2007) argue that the problems of regional integration have long been recognized in Africa's political circles. Many decades ago, Nkrumah forcefully stated the case for regionalism in Africa. While different integration mechanisms have been successfully launched by other regions to improve their economic welfare, Africa lags behind with regards to economic growth and general living standards. Among the features of the discourse on regional integration (Dzaka-Kikouta and Tchouassi, 2012) in Africa there are the absences of political constituencies in the business and labor movements that push for regional integration. However, it is very clear that what African leaders have not achieved domestically through sound economic development policies would be difficult to achieve regionally. This is why new methodology and data are used to analyze how trade liberalization and democracy impact development in Central Africa.

\section{Methodology and Data}

First, the empirical model to be used is specified and second the data sources are presented.

Empirical model specification: The purpose of the study is to analyze the impact of democracy on trade flows in order to channelize economic development in Central Africa countries. To attain this objective the gravity equation form is used (1). The gravity equation is based on the potential concept from physics. The idea is that two objects attract each other because of their size and their distance (Isard, 1954; Tinbergen, 1962). The gravity equation has a basic form:

$T_{i e}=\beta_{0} Y_{i}^{\beta 1} Y_{e}^{\beta 2} D_{i e} e^{\beta 3}$

where $Y_{i}$ and $Y_{e}$ are the masses of objects $i$ and $e$ or Gross domestic product (GDP) of two countries and $D_{i e}$ the actual distance between two objects or two countries. The gravity model assumes that there is attraction between the GDP of two countries $i$ and $j$, the same for attributes $i$ and $e$. Attraction can be interpreted as dependence between two variables. The practical implication is that there is no need to construct summary variables containing the information for country $i$ and $e$. From Aidt and Gassebner (2010), we estimate the relationship between a country's political regime and its involvement in international trade by testing (i) the effective trade distortion is higher in autocracies than in democracies and, as a consequence, autocracies trade less with the rest of the world than do democracies and; (ii) for given official trade policy, autocracies trade less with the rest of the world than do democracies because of differences in red tape and other unofficial trade distortions. In this model the dependent variable is imports of country $i$ from country $e$ in year $t$ rather than total trade flows between pairs of countries. This choice avoids what Baldwin (2006) calls the "silver-medal of gravity mistakes"-that is, the sizable upward bias that regressions with average bilateral trade flows as the dependent variable are subject to when trade is unbalanced. This follows from the fact that the log of the average is not equal to the average of the logs if the import and export flows are not identical in magnitude. For a formal proof, refer to Baldwin (2006).

More specifically, the baseline specification is the following dyadic panel model adapted from Aidt and Gassebner (2010):

$\ln \left(\right.$ import $\left._{i e t}\right)=\beta_{1}$ regime $_{i t-1}+\beta_{2}$ regime $_{e t-1}+\beta_{3} \ln \left(\mathrm{GDP}_{i t}\right)+\beta_{4} \ln \left(\mathrm{GDP}_{e t}\right)+\beta_{5} \ln \left(\mathrm{GDP}_{\mathrm{p} . \mathrm{it} t}\right)$ $+\beta_{6} \ln \left(\mathrm{GDP}_{\mathrm{p} . c . t}\right)+\beta_{7} \ln \left(\mathrm{WTO}_{i t}\right)+\beta_{8} \ln \left(\mathrm{WTO}_{e t}\right)+\beta_{5} \ln \left(\right.$ regional $\left._{i e t}\right)$

$+\gamma_{i e}+\delta_{t}+\varepsilon_{i e t}$

where import ${ }_{i e t}$ is imports of country $i$ from country $e$ in year $t$; regime $_{i t-1}$ and regime $e_{e t-1}$ are lagged values of measures of regime type (democracy or autocracy) of the importing and exporting country (to be discussed below); $\mathrm{GDP}_{i t}$ and $\mathrm{GDP}_{\text {et }}$ are real GDP of the importing and exporting country; $\mathrm{GDP}_{\text {p.c.it }}$ and $\mathrm{GDP}_{\text {p.c.et }}$ are GDP per capita of the importing and exporting country; $\mathrm{WTO}_{i t}$ and $\mathrm{WTO}_{e t}$ are dummy variables indicating whether the importer or exporter country is a member of the General Agreement on 
Tariffs and Trade/World Trade Organization (WTO); and regional ${ }_{\text {iet }}$ is a dummy variable taking the value of 1 if both the importer and the exporter are members of the same regional trade agreement. All regressions include fixed effects for the trading pair, $\gamma_{i e}$, as well as year fixed effects, $\delta_{t}$. $\varepsilon_{i e t}$ represent the error term.

The Human development index (HDI) is a composite statistic of life expectancy, education, and income indices used to rank countries into four tiers of human development. It was created by Mahbub ul Haq followed by Amartya Sen in 1990 (UNDP, 2012). We use Human development indicators to capture the development defined here as well-being. So the dependent variable here HDI can be written as follow:

$\mathrm{HDI}_{i t}=\beta_{1}$ Regime $_{i t}+\beta_{2}$ Import $_{i t}+\beta_{3}$ Export $_{i t}+\beta_{4}$ Pop $_{i t}+\beta_{5}$ Inflat $_{i t}$

$+\beta_{6} W T O_{i t}+\beta_{7}$ Regional $_{i t}+\delta_{t}+\varepsilon_{i j t}$

where $\mathrm{HDI}_{i t}$ is real HDI of the country $i$ at the time $t$; Pop ${ }_{i t}$ is population of the country $i$ at the time $t$; Inflat ${ }_{i t}$ is the inflation rate of country $i$ at the time $t$. Democracy is represented here by Regime $e_{i t}$ which is a dummy variable taking 1 if the political regime in the country $i$ is free and 0 else at the time $t$. Import ${ }_{i t}$ and Export $_{i t}$ are respectively importation and exportation of the country $i$ at the time $t$. Regional ${ }_{i t}$ is a dummy variable that takes 1 for CEMAC and 0 for CPGL. $\delta_{t}$ and $\varepsilon_{i j t}$ are respectively the specific time effect and the error term. And $t=1,2, \ldots, 16$ years is time from 1995 to 2010, $i=1,2, \ldots, 11$ countries. The different monetary values here are in current US Dollar.

In the current application, estimations, using regression analysis with fixed effect and random effect models, are done to evaluate the impact of democracy (political regime), importation, exportation, population, inflation, WTO and regional integration on Human development indicator.

Data sources: The panel considered in this study is balanced and made up of 11 Central Africa countries with 176 observations. Since independence, eleven developing countries in Central African region (Angola, Burundi, Cameroon, Central African Republic, Chad, Congo Republic, Democratic Republic of Congo, Equatorial Guinea, Gabon, Rwanda, Sao Tomé and Principe) experienced regionalism (the Central African Economic Community-CEEAC, Central African Monetary Community-CEMAC, and the Economic Community of the Great Lakes-CEPGL). Significant episodes of democratic political parties and multipartism systems with violent conflict between government and opposition groups were observed. Data used for this study was obtained from UNDP (2010), IMF (2012), and Freedom House (2010).

\section{Results}

The model (3) was estimated using fixed effects and random effects models. Results obtained from the estimations of the above models (fixed effects and random effects) are summarized in the Tables 1 and 2 as follow: Table 1 presents the results of the regression analysis using fixed effects. Using fixed effects model, ordinary least square (OLS) estimators will be efficient. Because of collinearity (the property of lying on a single line, aligned), the variables Regime, Regional and WTO were dropped. The R-square within is 0.2492 and the overall R-square is 0.2073 meaning that there is a relationship between HDI, inflation, importations and exportations.

Table 1: Results from fixed effects model

\begin{tabular}{|c|c|c|c|c|c|}
\hline $\begin{array}{l}\text { Fixed-effects } \\
\text { (within) } \\
\text { regression }\end{array}$ & $\begin{array}{l}\text { Number } \\
\text { of obs }\end{array}$ & $=$ & 176 & & \\
\hline $\begin{array}{l}\text { Group variable: } \\
\text { state }\end{array}$ & $\begin{array}{l}\text { Number of } \\
\text { groups }\end{array}$ & $=$ & 11 & & \\
\hline $\begin{array}{l}\text { R-square: } \\
\text { within } 0.2492\end{array}$ & $\begin{array}{l}\text { Obs per } \\
\text { group: } \min \end{array}$ & $=$ & 16 & & \\
\hline between 0.2455 & Avg & $=$ & 16.0 & & \\
\hline overall 0.2073 & $\begin{array}{l}\text { Max } \\
F(4,161)\end{array}$ & $\begin{array}{l}= \\
=\end{array}$ & $\begin{array}{l}16 \\
13.36\end{array}$ & & \\
\hline $\begin{array}{l}\operatorname{corr}\left(u_{\_} \mathrm{i}, \quad \mathrm{Xb}\right) \\
0.7908\end{array}$ & Prob > F & $=$ & 0.0000 & & \\
\hline $\begin{array}{l}\text { hdi } \\
\text { wto } \\
\text { regional }\end{array}$ & $\begin{array}{l}\text { Coef. } \\
\text { (dropped) } \\
\text { (dropped) }\end{array}$ & Std. Err. & $P>|t|$ & $\begin{array}{l}{[95 \%} \\
\text { Interval] }\end{array}$ & Conf. \\
\hline
\end{tabular}




\begin{tabular}{|c|c|c|c|c|c|c|}
\hline regime & (dropped) & & & & & \\
\hline inflation & -.0000114 & $5.55 \mathrm{e}-06$ & -2.05 & 0.042 & $\begin{array}{l}-.0000223 \\
4.13 e-07\end{array}$ & \\
\hline population & .0049607 & .0008462 & 5.86 & 0.000 & $\begin{array}{l}.0032897 \\
.0066317\end{array}$ & \\
\hline export & -.0000575 & .000039 & -1.47 & 0.142 & $\begin{array}{l}-.0001345 \\
.0000195\end{array}$ & \\
\hline import & .0000778 & .0000785 & 0.99 & 0.323 & $\begin{array}{l}-.0000772 \\
.0002329\end{array}$ & \\
\hline _cons & .3516499 & .0096732 & 36.35 & 0.000 & $\begin{array}{l}.3325471 \\
.3707527\end{array}$ & \\
\hline $\begin{array}{l}\text { sigma_u } \\
\text { sigma_e }\end{array}$ & $\begin{array}{l}.17544559 \\
.02455805\end{array}$ & & & & & \\
\hline rho & .98078342 & (fraction & \multirow{2}{*}{\multicolumn{2}{|c|}{$\begin{array}{l}\text { of variance due } \\
F(10,161)\end{array}$}} & to & u_i) \\
\hline $\mathrm{F}$ & $\begin{array}{l}\text { test that } \\
\text { all }\end{array}$ & $\mathrm{u}_{-} \mathrm{i}=0$ : & & & $=259.75$ & $\begin{array}{l}\text { Prob }>F= \\
0.0000\end{array}$ \\
\hline
\end{tabular}

Source: Author's calculation

Applying random effects model, ordinary least square (OLS) estimators will not be efficient and the appropriate method of estimation will be the generalized least squares (GLS). GLS are techniques employed for estimating the unknown parameters in a linear regression model. In this case ordinary least squares are statistically inefficient. The GLS is applied here because the variances of the observations are unequal, and there is a certain degree of correlation between the observations. Table 2 presents the results of the regression analysis using random effects. Because of collinearity, the variable WTO was dropped. The overall R-square is 0.0325 showing that there is a relationship between HDI, democracy, regional, importations, exportations and inflation.

Table 2: Results from random effects model

\begin{tabular}{|c|c|c|c|c|c|c|}
\hline $\begin{array}{l}\text { Random- } \\
\text { effects GLS } \\
\text { regression }\end{array}$ & $\begin{array}{l}\text { Number of } \\
\text { obs }\end{array}$ & $=$ & 176 & & & \\
\hline $\begin{array}{l}\text { Group } \\
\text { variable: state }\end{array}$ & $\begin{array}{l}\text { Number of } \\
\text { groups }\end{array}$ & $=$ & 11 & & & \\
\hline $\begin{array}{l}\text { R-square: } \\
\text { within } 0.2486\end{array}$ & $\begin{array}{l}\text { Obs per } \\
\text { group: min }\end{array}$ & $=$ & 16 & & & \\
\hline $\begin{array}{l}\text { between } \\
0.0288\end{array}$ & avg & $=$ & 16.0 & & & \\
\hline overall 0.0325 & $\max$ & $=$ & 16 & & & \\
\hline $\begin{array}{l}\text { Random } \\
\text { effects u_i } \sim \\
\text { Gaussian }\end{array}$ & Wald chi2(6) & $=$ & 50.67 & & & \\
\hline $\begin{array}{l}\operatorname{corr}\left(\mathrm{u}_{-} \mathrm{i}, \quad \mathrm{X}\right) \\
\text { (assumed) }\end{array}$ & Prob > chi2 & $=$ & 0.000 & & & \\
\hline hdi & Coef. & Std. Err. & $\mathrm{z}$ & $\mathrm{P}>|\mathrm{z}|$ & [95\% Conf. & Interval] \\
\hline regional & 1279116 & .0898253 & 1.42 & 0.154 & -.0481427 & .303966 \\
\hline regime & .135838 & 1003511 & 1.35 & 0.176 & -.0608466 & .3325225 \\
\hline inflation & -.0000122 & $5.56 \mathrm{e}-06$ & -2.19 & 0.028 & -.0000231 & $-1.30 \mathrm{e}-06$ \\
\hline population & .0044924 & .000821 & 5.47 & 0.000 & .0028832 & .0061015 \\
\hline export & -.0000568 & .0000391 & -1.45 & 0.146 & -.0001335 & .0000199 \\
\hline import & .0000856 & .0000787 & 1.09 & 0.277 & -.0000686 & .0002399 \\
\hline _cons & .2500575 & .0702459 & 3.56 & 0.000 & .1123781 & .3877369 \\
\hline sigma_u & .14528969 & & & & & \\
\hline sigma_e & .02455805 & & & & & \\
\hline & .97222308 & (fraction & of var & ance due & to & u_i) \\
\hline hdi & Coef. & Std. Err. & $\mathrm{z}$ & $P>|z|$ & [95\% Conf. & Interval] \\
\hline regional & .1279116 & .0898253 & 1.42 & 0.154 & -.0481427 & .303966 \\
\hline
\end{tabular}

Source: Author's calculation 
The random effects is efficient, and should be used (over fixed effects) if the assumptions underlying it are believed to be satisfied. This can be tested by running random effects, then fixed effects, and doing a Hausman specification test. Using Hausman test (Table 3 below), the random effects is inconsistent under alternative hypothesis (Ha) and efficient under null hypothesis (Ho). The fixed effect is consistent under null hypothesis and alternative hypothesis.

Table: 3: Results from the test of difference in coefficients

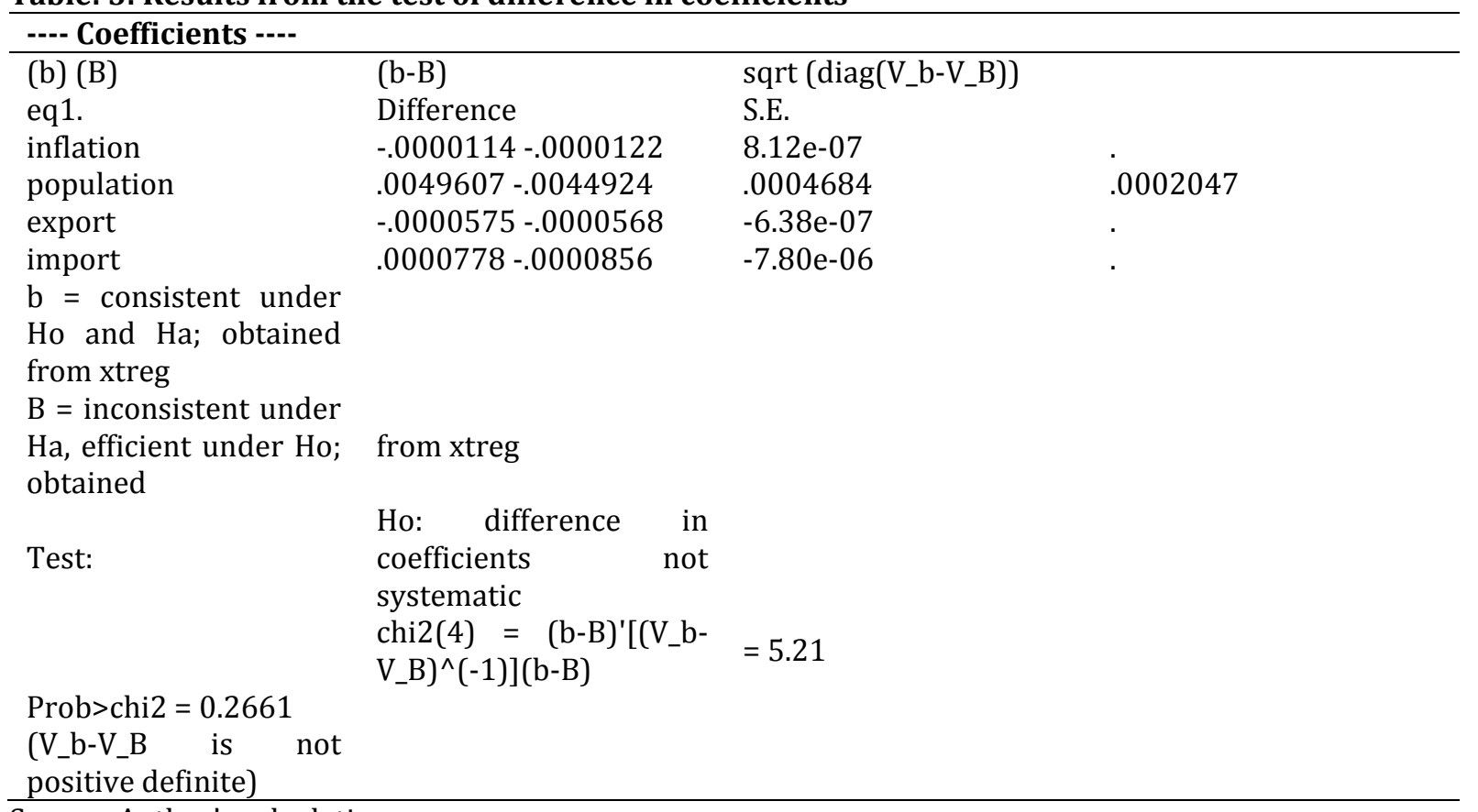

Source: Author's calculation

Inflation and exports negatively affect the well-being of the population. An increase in inflation rate causes a reduction in purchasing power. An increased in exports commodities tends to decrease the quantity of goods available for the country of origin. Imports have a positive effect on the Human development indicators (HDI) probably because this variable tends to increase the quantity of goods available. So importation is one of the mechanisms of trade liberalization driving well-being of populations and economic development in Central Africa. The variable democracy (capture here by regime) has a positive effect on the Human development indicators. This implies that democratic political system positively affects the level of development. Political regime is one of the main channels driving development in Central Africa Region. Aidt and Gassebner (2010) found before that autocracies trade less than democracies. Their analysis shows that autocracies import less and export less. This effect is driven not only by differences in trade policy but also by systematic differences in political accountability and good governance program. A democratic country trades more with the rest of the world because democratically elected politicians are less tempted to use trade taxes to extract rents. Other explanations are also consistent with the results. For example, rulers must cater to powerful domestic elites who have a special interest in trade protection in many autocracies, as they often have a substantial stake in importcompeting sectors. However, lobbying by special interests groups for trade protection is also common in democracies. It is, therefore, unclear if this line of reasoning leads to systematic regime differences in trade flows. Instead of the existence of varieties of democracy and varieties of development the notion of democratic countries is inextricably linked to the concept of freedom. However, the constant term is positive. This means that in the countries with other types of political system the Human development indicators still positive. This result can be explained by the existence of varieties of democracy in Central Africa region and by the fact that a democratic political system is not a necessary and sufficient condition for economic development.

\section{Conclusion}

Previous studies established that there is a relationship between political regime, trade flows and economic growth. This paper contributes to the existing literature by empirically answered the research 
question: can trade liberalization and democracy help to enhance development in Central Africa region. The study examined the effects of trade liberalization and democracy on economic development during the period 1995 - 2010. Random effects model was used to analyze the relationships. Results obtained from the empirical model show that imports and democracy have a positive effect on the Human development indicators. Policy suggestion corroborates arguments that autocratic countries are less integrated in world trade than democratic countries. Findings are similar to Aidt and Gassebner (2010). Trade liberalization and democracy are seen as drivers of economic development. Lessons learn from this are that trade liberalization, democracy and regional economic integration must be viewed as important for driving Central Africa's human development. This is possible by instituting credible interdependent free trade policies among the countries. The formation of the democratic developmentalism region results in economic growth, through attracting human and capital resources, and democratic technology innovation to transform economies, increase trade creation (opposite to trade diversion), expand economies of scale, reduce the cost of doing business, and promote regional peace and security. In the Central Africa region, many countries inadequately develop a framework that links trade liberalization and democracy to build human well-being because of the lack of accountability and good governance. This is why the capacity building on "good governance agenda" fostered by many international institutions is a very important program used to counterbalance the negative impact that varieties democracy regimes have on the regional economic integration in Central Africa and on economic growth. The paper's findings are important to Central Africa policy makers towards creation and increasing trade within, between and with other democratic countries. Using other methodologies, cross-sectional approach for example, can help to capture more specific effect of political regime and trade liberalization on economic development to extend this study.

\section{References}

Acemoglu, D., Simon Johnson, D., Robinson, J. A. \& Yared, P. (2008). Income and Democracy. American Economic Review, 98(3), 808-42.

Acemoglu, D. \& Robinson, J. A. (2006). Economic Origins of Dictatorship and Democracy. Cambridge University Press, Cambridge.

Aidt, T. S. \& Gassebner, M. (2010). Do Autocratic States Trade Less? The World Bank Economic Review, 24(1), 38-76 doi:10.1093/wber/lhp022

Arnfred, S. \& Utas, M. (2007). Re-thinking Africa. A Contribution to the Swedish Government White Paper on Africa, The Nordic Africa Institute, Uppsala.

Balassa, B. (1961). Towards a Theory of Economic Integration. Irwin, Homewood, Illinois.

Baldwin, R. R. (2006). The Euro's Trade Effects. European Central Bank Working Paper WPS/594, Frankfurt, Germany.

Barbierie, K. (1996). Economic Interdependence: A path to peace or source of interstate conflict? Journal of Peace Research, 33(1), 29-49.

Barbierie, K. (2003). The Liberal Illusion: Does trade promote peace? The University of Michigan Press.

Barro, R. (1999). Determinants of Democracy. Journal of Political Economy, 107(S6), S158-83.

Boockmann, B. \& Dreher, A. ( 2003). The Contribution of the IMF and the World Bank to Economic Freedom. European Journal of Political Economy, 19(3), 633-49.

Brunetti, A. \& Weder, B. (1995). Political Sources of Growth: A Critical Note on Measurement. Public Choice, 82(1-2), 125-34.

Burkhart, R. E. \& Lewis-Beck, M. S. (1994). Comparative Democracy: The Economic Development Thesis. American Political Science Review, 88(4), 903-10.

Coppedge, M. \& Wolfgang, R. (1990). Measuring Polyarchy. Studies in Comparative International Development, 25(1), 51-72.

Daumal, M. (2008), Federalism, Separatism and International Trade. European Journal of Political Economy, 24(3), 675-87.

Draper (2010). Rethinking the (European) Foundations of Sub-Saharan African Regional Economic Integration: A Political Economy Essay. Working Paper, 293, OECD.

Dreher, A. \& Rupprecht, S. (2007). IMF Programs and Reform-Inhibition or Encouragement? Economics Letters, 95(3), 320-26.

Durham, J. B. (1999). Economic Growth and Political Regimes. Journal of Economic Growth, 4(1), 81-111.

Dzaka-Kikouta, T. \& Tchouassi, G. (2012). Intégration régionale en Afrique Centrale: Une analyse des théories, des contraintes et des perspectives. In Fau-Nougaret M. (sd), La concurrence des organisations régionales en Afrique, L'Harmathan, Paris. 
Fedderke, J. \& Klitgaard, R. (1998). Economic Growth and Social Indicators: An Exploratory Analysis. Economic Development and Cultural Change, 46(3), 455-90.

Feng, Y. (1996). Democracy and Growth: The Sub-Saharan African Case, 1960-1992. Review of Black Political Economy, 25(1), 95-126.

Freedom House (2010). Annual Survey of Freedom Country Scores. http://www. freedomhouse.org.rankings.pdf/.

Gasiorowski, M. J. (2000). Democracy and Macroeconomic Performance in Underdeveloped Countries. Comparative Political Studies, 33(3), 319-49.

Giavazzi, F. \& Tabellini, G. (2005). Economic and Political Liberalizations. Journal of Monetary Economics, 52(7), 1297-1330.

Goldsmith, A. A. (2001). Foreign Aid and Statehood in Africa. International Organization, 55(1), 123-148

Helliwell, J. F. (1994). Empirical Linkages between Democracy and Economic Growth. British Journal of Political Science, 24(2), 225-48.

Hettne, B. (2000). The new regionalism and the future of security and development. MacMillan, London.

IMF. (2012). World Economic Outlook. Growth Resuming, Dangers Remain, http://www.imf.org

Isard, W. (1954). Location Theory and Trade Theory: Short-Run Analysis. Quarterly Journal of Economics, $68,305-322$.

Hugon, P. (1993). Les économies en développement à l'heure de la régionalisation. Karthala, Paris.

Krueger, A. O. (1974). The political economy of the rent-seeking society. American Economy Review, 64(3), 291-303.

Krugman, P. R. (1991). Geography and Trade. MIT Press, Cambridge.

Krugman, P. R. (1996). Pop internationalism. MIT Press, Cambridge.

Krugman, P. R. \& Obstfeld, M. (2006). International economics: theory and policy. $7^{\text {th }}$ edition, Pearson/Addison-Wesley, Boston.

Kwa A. (2007), Rethinking the Trading System, Dialogue on Globalization. Occasional Papers, 32, Friedrich-Ebert-Stiftung (FES), Geneva.

Leblang, D. A. (1997).Political Democracy and Economic Growth: Pooled Cross-sectional and Time-series Evidence. British Journal of Political Science, 27(3),-453-72.

Li, Q. \& Reuveny, R. (2003). Economic Globalization and Democracy: An Empirical Analysis. British Journal of Political Science, 33(1), 29-54.

Lipsey, R. G. (1957). The Theory of Customs Unions. Economica, Paris.

Little, I. M. D., Scitovsky, T. \& Scott, M. (1970). Industry and Trade in Some Developing Countries. Oxford University Press, Oxford.

Long, A. G. (2008). Bilateral Trade in the Shadow of Armed Conflict. International Studies Quarterly, 52, 81-101.

Lopez-Cordova, J. E. \& Meisner, M. C. (2008). The Impact of International Trade on Democracy: A Longrun Perspective. World Politics, 60(4), 539-75.

Mansfield, E. D., Milner, H. V. \& Rosendorff, B. P. R. (2000). Free to Trade: Democracies, Autocracies, and International Trade. American Political Science Review, 94(2), 305-321.

Martin, P., Mayer, T. \& Thoenig, M. (2008). Make trade not war? Review of Economic Studies, 75(3), 865900

Mbaku, J. M. (1994). The Political Economy of Development: An Empirical Analysis of the Effect of the Institutional Framework on Economic Development. Studies in Comparative International Development, 29, 3-21.

Meade, J. E. (1956). The Theory of Customs Unions. Amsterdam, North Holland.

Milner, H. V. \& Kubota, K. (2005). Why the Move to Free Trade? Democracy and Trade Policy in the Developing Countries. International Organization, 59(1), 107-143.

Morrow, J. D., Siverson, R. M. \& Tabares, T. E. (1998). The Political Determinants of International Trade: The Major Powers, 1907-90. American Political Science Review, 92(3), 649-61.

Mousseau, M. (2000). Market Prosperity, Democratic Consolidation, and Democratic Peace. Journal of Conflict Resolution, 44(4), 472-507.

Myrdal, G. (1971). Asian Drama, an Inquiry into the Poverty of Nations. Penguin Books, London.

Nelson, M. A. \& Singh, R. D. (1998). Democracy, Economic Freedom, Fiscal Policy, and Growth in LDCs: A Fresh Look. Economic Development and Cultural Change, 46(4), 677-96.

Oneal, R. J. \& Russet, B. (1999). Assessing the Liberal Peace with Alternative Specifications: Trade Still Reduces Conict. Journal of Peace Research, 36(4), 423-442.

Oneal, R. J. \& Russet, B. (2003). Clear and Clean: The Fixed Effects of Liberal Peace. International Organization, 55(2), 469-485. 
Ohno, K. (2009). Ethiopia: Political Regime and Development Policies. GRIPS Development Forum, Tokyo. Perroux, F. (1961). L'économie du XXe siècle. Presses Universitaires de Grenoble, Grenoble.

Perroux, F. (1972). Masse et classe. Casterman, Paris.

Polachek, S. W. (1980). Conflict and Trade. Journal of Conflict Resolution, 1, 55-76.

Polachek, S. W. (2007). Trade, Peace and Democracy: An analysis of dyadic dispute. In Sandler Todd and Hartley Keith Handbook of Defense Economics, 2, 31.

Przeworski, A. \& Limongi, F. (1997). Democracy and Development. In Democracy's Victory and Crisis, edited by Axel Hadenius, 163-94. Cambridge University Press, Cambridge.

Rigobon, R. \& Rodrik, D. (2005). The Rule of Law, Democracy, Openness and Income: Estimating the Interrelationships. Economics of Transition, 13(3), 533-64.

Rodriguez-Clare, A. (1996). Multinationals, Linkages, and Economic Development. American Economic Review, 86(4), 852-73.

Romer, P. (1994). New Goods, Old Theory, and the Welfare Costs of Trade Restrictions. Journal of Development Economics, 2, 5-38.

Rostow, W. W. (1960). The stages of economic growth: a non-communist manifesto. Cambridge University Press, Cambridge.

Sachs, J. D. \& Warner, A. M. (1995). Economic Reform and the Process of Global Integration. Brookings Papers on Economic Activity, 1-95.

Sen, A. (1999). Development as freedom. Oxford University Press, Oxford.

Sen, A. (2000). Un nouveau modèle économique. Développement, justice, liberté. Odile Jacob, Paris.

Serieux, J. (1999). Democratization and Structural Adjustment in Africa: An Empirical Investigation. Canadian Journal of Development Studies, 20 (3), 521-544.

Smith, A. (1776). The Wealth of Nations. ed. Andrew Skinner, Penguin Books, Harmondsworth.

Stiglitz, J. E. (1997). Trade and Technology: Links and Problems. Paper presented to the Annual World Bank Conference on Development in Latin America and the Caribbean. Montevideo, Uruguay.

Stiglitz, J. E. (1998). Towards a New Paradigm for Development: Strategies, Policies, and Processes, Prebisch Lecture at UNCTAD, Geneva.

Sturm, J. E. \& de Haan, J. (2003). Does More Democracy Lead to Greater Economic Freedom? New Evidence for Developing Countries. European Journal of Political Economy, 19(3), 547-63.

Tinbergen, J. (1962). Shaping the World Economy: Suggestions for an International Policy. The Twentieth Century Fund.

UNDP. (2010). Human Development Report 2010. 20th Anniversary Edition, the Real Wealth of Nations: Pathways to Human Development. http://hdr.undp.org UNDP (2012). The Human Development concept. UNDP, Retrieved 7 April 2012.

Van de Walle, N. (1999). Economic Reform in a Democratizing Africa. Comparative Politics, 32(1), 21-41.

Viner, J. (1950). The Customs Union Issue. Carnegie Endowment for International Peace, New York

Wade, R. H. (2008). How to change the WTO and global policy on trade and investment: gaining acceptance of open economy industrial policy by hoisting neoliberalism on its own petard, Note for Princeton conference on Normative and empirical evaluation of global governance, February 1618.

Wade, R. H. (2003). What strategies are viable for developing countries today? The WTO and the shrinking of 'development space. Review of International Political Economy, 10(4).

Wickrama, K. A. S. \& Mulford, C. L. (1996). Political Democracy, Economic Development, Disarticulation, and Social Well-being in Developing Countries. Sociological Quarterly, 37(3), 375-90.

Williamson, J. (1990). Latin American Adjustment: How Much Has Happened?, Institute for International Economics, Washington D.C.

World Bank. (2008). World Development Indicators 2008. Oxford University Press, New York. 